\title{
Perancangan Website Media Informasi dan Pemesanan pada PT. Trita Musi Prasada dengan Metode RAD
}

\author{
Deri Susanti, Elmiyati
}

Sekolah Tinggi Manajemen Informatika dan Komputer Palcomtech, Palembang, Indonesia

\section{Article Info}

Article history:

Received, 25 April 2020

Revised, 9 May 2020

Accepted, 28 May 2020

\section{Kata kunci:}

Website

Informasi

Pemesanan

RAD

Media

\begin{abstract}
ABSTRAK
Perseroan Terbatas (PT). Trita Musi Prasada adalah salah satu perusahaan produksi air minum dalam kemasan (AMDK). Proses penyampaian informasi dan pemesanan yang berjalan di PT. Trita Musi Prasada pada saat ini masih konvensional yaitu dilakukan dengan cara sales berkunjung langsung ke tokotoko atau distributor untuk memberikan slide presentasi dan kartu nama serta konsumen datang langsung ke perusahaan untuk melakukan pemesanan produk. Kedua cara tersebut ternyata belum efektif karena informasi yang didapat konsumen tidak lengkap, hal itu menyebabkan target pasar masih minim karena keterbatasan jangkauan pemasaran produksi. Alat merancang website ini menggunakan flowchart, diagram konteks, (DFD) Data Flow Diagram, (ERD) Entity Relationship Diagram dan pengembangan sistem yang digunakan dengan metode Rapid Application Development (RAD). Dengan adanya website media informasi ini dirancang untuk mempermudah perusahaan dalam mengenalkan perusahaan kepada masyarakat dan menawarkan produk sekaligus sebagai media pemesanan produk. Dengan adanya website media informasi dan pemesanan produk atau barang pada PT. Tirta Musi Prasada ini dapat dengan mudah melakukan pemesanan dengan mengunjungi website dan mempermudah perusahaan dalam mengenalkan perusahaan dan promosi kepada masyarakat dan menawarkan produk sekaligus sebagai media pemesanan produk dengan jangkauan lebih luas.
\end{abstract}

\section{ABSTRACT}

Keywords:

Website

Information

Booking

RAD

Media

PT. Trita Musi Prasada is one of the bottled water production companies (AMDK). The process of delivering information and ordering that runs at PT. Trita Musi Prasada at this time is still conventional, which is done by selling directly to shops or distributors to give presentation slides and business cards and consumers come directly to the company to order products. Both of these methods are apparently not yet effective because the information obtained by consumers incomplete, it causes the target market is still minimal because of the limited marketing reach of production. This website design tool uses flowcharts, context diagrams, (Data Flow Diagram) DFD, (Entity Relationship Diagram) ERD and system development used by the Rapid Application Development (RAD) method. With the information media website and ordering products or goods at PT. Tirta Musi Prasada can easily place an order by visiting the website and facilitate the company in introducing the company and promotions to the public and offering products as well as a medium for ordering products with a wider range.

This is an open access article under the CC BY-SA license.

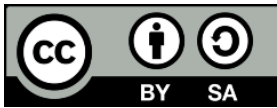

\section{Penulis Korespondensi:}

Deri Susanti,

Program Studi Sistem Informasi,

Sekolah Tinggi Manajemen Informatika dan Koputer Palcomtech.

Email: deri_susanti@palcomtech.ac.id 


\section{PENDAHULUAN}

Website sangat efektif digunakan sebagai media informasi karena terdapat unsur visual berupa gambar dan teks yang dapat membuat konsumen terkesan sehingga menimbulkan daya tarik dan kepercayaan terhadap suatu perusahaan [1]. Untuk melakukan bisnis, website memiliki peranan yang sangat penting sebagai media informasi detail mengenai perusahaan dan juga sebagai media publikasi. PT. Trita Musi Prasada adalah salah satu perusahaan produksi air minum dalam kemasan (AMDK). Proses Penyampaian informasi dan pemesanan produk yang berjalan di PT. Trita Musi Prasada pada saat ini masih konvensional, yaitu penjualan dan promosi dilakukan dengan cara sales/marketing berkunjung langsung ketoko-toko atau distributor untuk memberikan informasi dan menawarkan produk seperti memberikan slide presentasi dan kartu nama. Kedua cara tersebut ternyata belum efektif dikarenakan banyaknya waktu yang diperlukan oleh marketing untuk berkunjung dan masih banyak tempat yang belum bisa dijangkau oleh marketing karena keterbatasan waktu dan jarak serta informasi yang diberikan belum lengkap sehingga menyebabkan target pasar masih sangat minim.

Untuk mengatasi semua permasalahan yang ada pada PT. Trita Musi Prasada yaitu salah satunya membuat website media informasi dan pemesanan. Hal ini bertujuan mempermudah calon konsumen mendapatkan informasi dan dapat memfasilitasi konsumen melakukan pemesanan produk secara online.

Website media informasi dan pemesanan barang pada PT. Tirta Musi Persada dibangun dengan menggunakan metode Rapid Application Development (RAD). RAD atau rapid prototyping adalah model proses pembangunan perangkat lunak yang tergolong dalam teknik inkremental (bertingkat), karena dalam perancangannya sangat singkat dan cepat [2].

Dengan adanya website media informasi dan pemesanan barang pada PT. Tirta Musi Prasda ini bertujuan untuk membantu PT. Tirta Musi Prasada dalam melakukan transaksi penjualan dan mempermudah marketing dalam memperluas promosi serta menghemat waktu dan biaya untuk melakukan promosi produk.

\section{METODE PENELITIAN}

Metodologi dalam melakukan penelitian ini, penulis menggunakan metode Rapid Application Development. RAD [3] merupakan pendekatan berorientasi objek terhadap pengembangan sistem yang mencakup suatu metode pengembangan serta perangkat-perangkat lunak yang memiliki tahapan-tahapan yang dapat lihat pada Gambar 1.

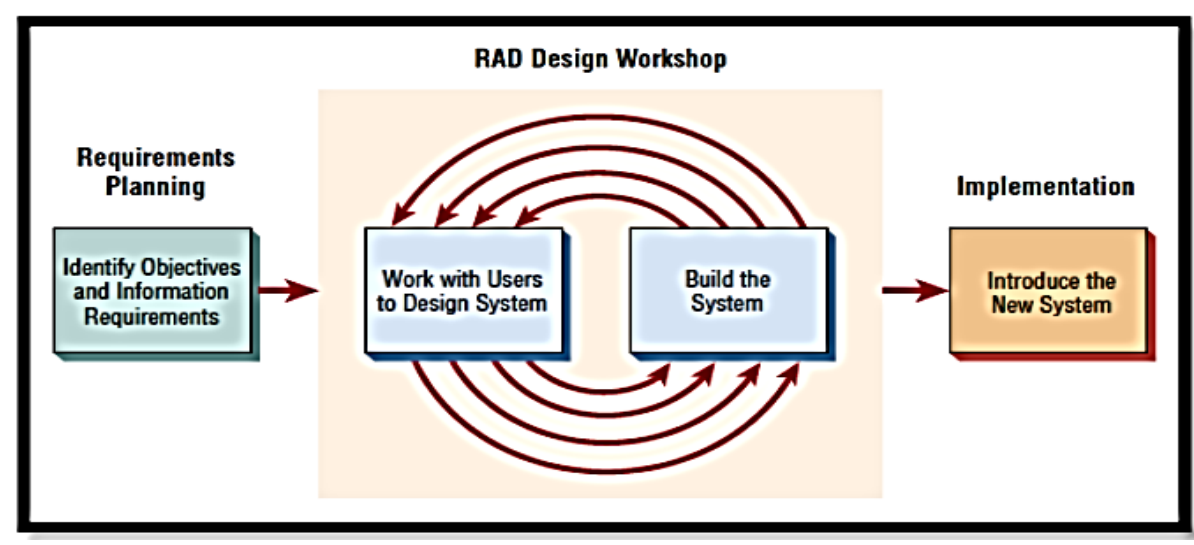

Gambar 1. Rapid Application Development (RAD) [4]

Berikut ini penjelasan tahap-tahapan dari metode RAD:

1. Requirement planning (perencanaan kebutuhan)

Requirement planning merupakan proses menganalisa kebutuhan yang lebih spesifik untuk kebutuhan perangkat lunak, agar dapat dipahami kebutuhan perangkat lunaknya oleh pengguna baik dalam sisi user dan admin.

2. Design workshop (perancangan dan perbaikan)

Pada tahapan ini dilakukan dengan merancang desain website informasi dan pemesanan sesuai kebutuhan dimulai dari alur proses yang berjalan dan alur proses yang diusulkan, diagram konteks, DFD, ERD, desain database, desain tampilan berdasarkan informasi dan masukan-masukan yang diberikan oleh pihak PT. Trita Musi Prasada. 


\section{Implementation (implementasi)}

Tahap implementasi merupakan tahap meletakan sistem supaya siap untuk dioperasikan. Dalam tahapan ini penulis membangun aplikasi menggunakan bahasa pemrograman PHP dan MySQL sebagai basisdatanya dan melakukan pengujian terhadap sistem yang telah dibuat menggunakan metode blackbox untuk memastikan form dan menu berfungsi dengan baik sebelum digunakan. Sistem yang telah diuji kemudian diimplementasikan di PT. Trita Musi Prasada dan siap untuk digunakan.

\section{HASIL DAN ANALISIS}

Interpretasi dari perancangan website sebagai media informasi dan pemesanan pada PT. Tirta Musi Prasada ini dengan menggunkan metode RAD yang merupakan metodologi perancangan secara cepat dan dapat bekerja secara sistematis dan terprosedur [5]. Website ini memiliki kemampuan untuk dapat diakses dan melakukan transaksi pemesanan dengan mudah sehingga perusahaan dapat melakukan promosi dengan biaya yang lebih rendah. Pada perancangan website sebagai media informasi dan pemesanan ada beberapa pembahasan diantaranya:

\subsection{Requirement planning}

Adapun langkah yang telah dilakukan peneliti dalam tahap requirement planning (perencanaan kebutuhan) ini adalah:

\subsubsection{Wawancara}

Wawancara (interview) adalah salah satu kaedah pengumpulan data yang paling biasa digunakan dalam penelitian dan merupakan proses yang paling penting dilakukan dalam penelitian kualitatif [6]. Dalam penelitian ini penulis melakukan wawancara langsung dengan bapak Suryadi selaku pimpinan PT. Trita Musi Prasada mengenai permasalahan yang ada pada perusahaan yakni adanya kendala dalam penyampaian informasi produk dan perusahaan serta pemesanan produk karena belum tersedianya website khusus yang dapat digunakan sebagai media informasi dan pemesanan.

\subsubsection{Observasi}

Obsevasi adalah pengamatan langsung para pembuat keputusan berikut lingkungan fisiknya dan atau pengamatan langsung suatu kegiatan yang sedang berjalan [7]. Melakukan observasi dengan mengamati langsung masalah alur kerja dan proses dalam kegiatan operasional pada PT. Trita Musi Prasada.

\subsubsection{Studi pustaka}

Metode pengumpulan data dilakukan dengan cara mempelajari berbagai laporan-laporan ilmiah dan dokumen atau sumber bacaan serta buku-buku yang berkaitan atau berhubungan dengan sistem usulan penelitian [8]. Penulis melakukan studi pustaka dengan mengumpulkan informasi berupa teori-teori yang berkaitan dengan penelitian.

\subsubsection{Dokumentasi}

Melakukan dokumentasi terhadap dokumen terkait dengan peneltian seperti data produk, data harga, dan data company profile.

\subsection{Design workshop}

Perancangan dalam membuat website sebagai media informasi dan media pemesanan ini menggunakan $w e b$. Web dapat diartikan sebagai kumpulan halaman yang menampilkan informasi data teks, gambar, animasi, suara, video dan gabungan dari semuanya, baik yang bersifat statis maupun dinamis yang membentuk satu rangkaian bangunan yang saling terkait, dimana masing-masing dihubungkan dengan jaringan-jaringan halaman (hyperlink) [8].

$W e b$ adalah sekumpulan halaman yang terdiri dari beberapa halaman yang berisi informasi dalam bentuk data digital baik berupa teks, gambar, video, audio, dan animasi lainnya yang disediakan melalui jalur koneksi internet [9]. Penulis menyimpulkan bahwa web adalah sebuah software yang berfungsi untuk menampilkan dokumen-dokumen pada suatu web yang membuat pengguna dapat mengakses internet melalui software yang terkoneksi dengan internet, dan menggunakan flowchart untuk menggambarkan aliran sistem. sesuai respon pengguna, membangun, dan menunjukkan pola kerja website kepada pengguna. Disini menyajikan flowchart yang berjalan, flowchart yang diusulkan, DFD, dan ERD [10].

Flowchart dapat berarti memrepresentasikan aliran sistem informasi, proses-proses, aliran-aliran datalogis, masukan-masukan, keluaran-keluaran, dan file-file juga entitas-entitas sistem operasi yang 
berhubungan dengan sistem informasi tersebut. Sistem flowchart berisi kegiatan-kegiatan logis dan fisik dari siapa, apa, bagaimana, dan dimana proses informasi dan operasi proses terjadi [11].

\subsubsection{Flowchart yang berjalan}

Untuk flowchart sistem informasi yang berjalan saat ini dapat dilihat pada Gambar 2.

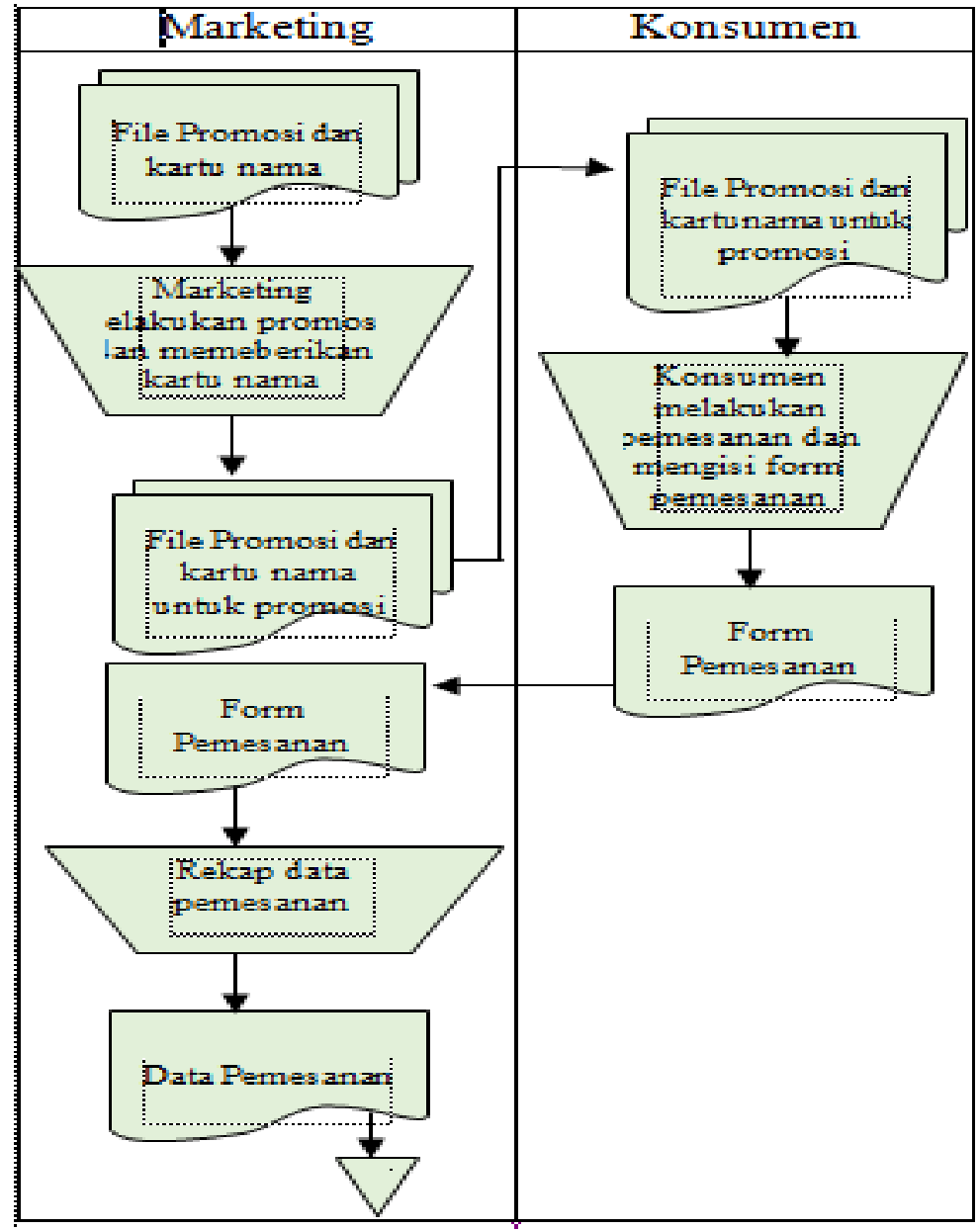

Gambar 2. Flowchart Penyampaian Informasi dan Pemesanan

\subsubsection{Flowchart yang diusulkan}

Flowchart yang diusulkan merupakan gambaran dari sistem yang akan dibuat, sehingga penulisan ini lebih terstruktur.

1. Flowchart yang diusulkan untuk admin.

Flowchart ini menggambarkan aliran sistem informsi yang diusulkan akan dapat membantu dan mempermudah bagian admin dalam menjalankan tugas dan fungsinya. Aliran flowchart dapat dilihat pada Gambar 3.

2. Flowchart yang diusulkan untuk user (Konsumen),

Flowchart ini menggambarkan aliran sistem informasi yang diusulkan untuk dapat membantu dan mempermudah bagian User dalam menjalankan tugas dan fungsinya. Aliran flowchart, dapat dilihat pada Gambar 4. 


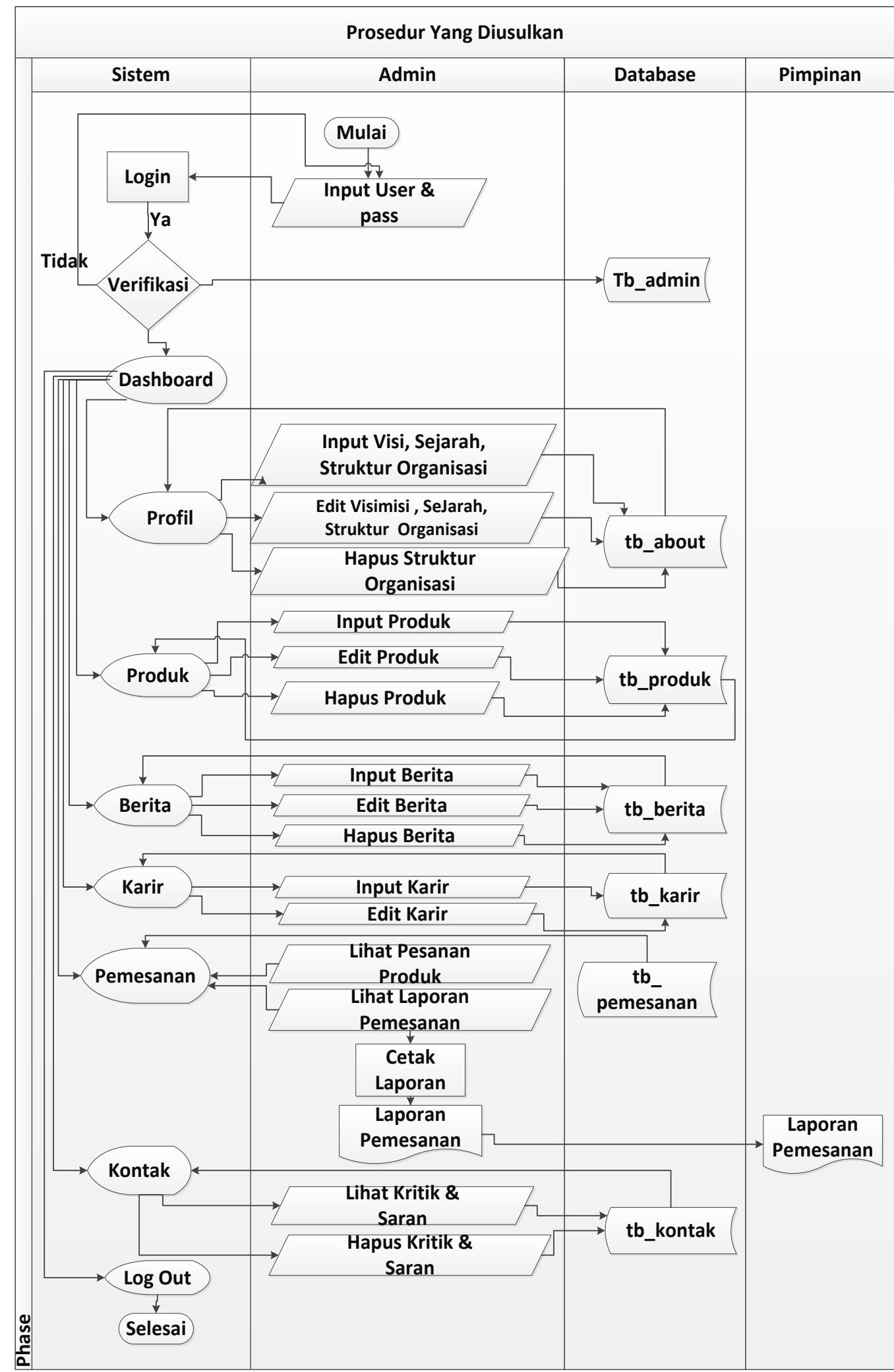

Gambar 3. Flowchart yang diusulkan untuk Admin 


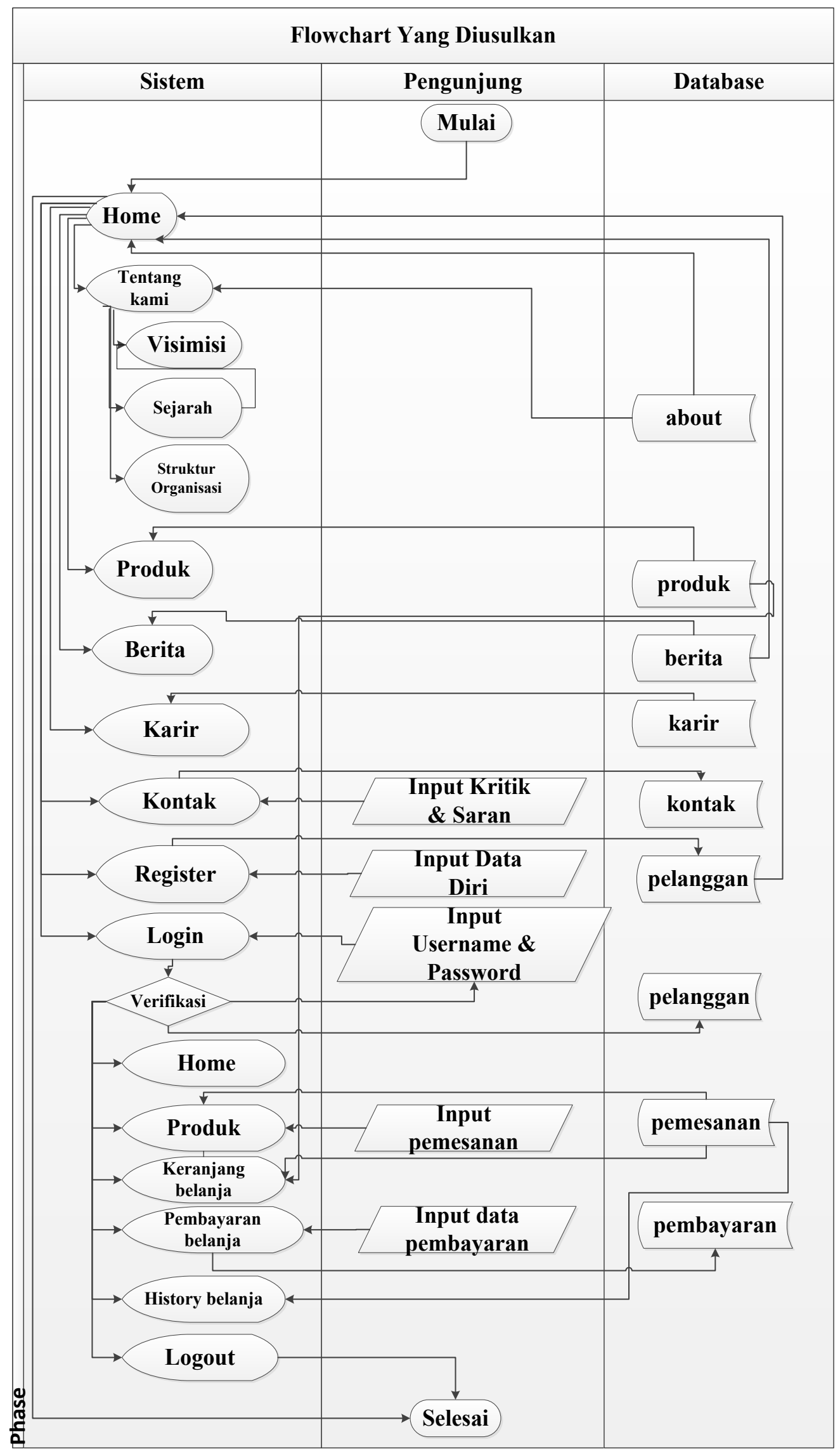

Gambar 4. Flowchart yang Diusulkan untuk User 


\subsubsection{Data Flow Diagram}

Data Flow Diagram, merupakan suatu proses data yang bergambarkan dari mana asal data dan kemana tujuan data tersebut keluar dari sistem dan disimpan [12] dapat dilihat pada Gambar 5.

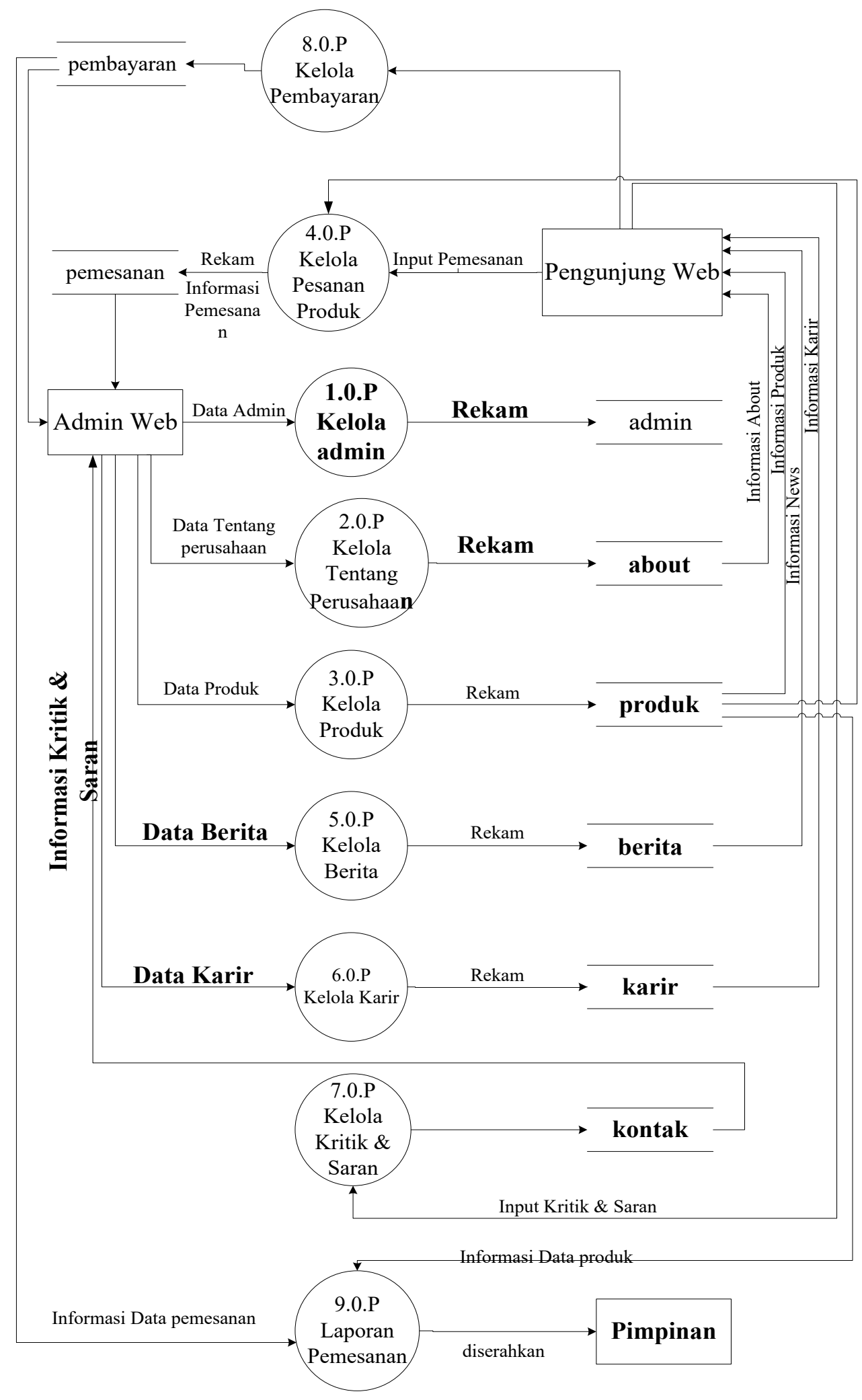

Gambar 5. DFD Level 0 


\subsubsection{Entity Relationship Diagram}

Entity Relationship Diagram, merupakan hubungan penterjemah yang berisi komponen-komponen himpunan entitas dan himpunan relasi yang dilengkapi dengan atribut-atribut dimana untuk menghubungkan entity tersebut digunakan key field (primary key) dari masing-masing entitas [13]. ERD merupakan model konseptual yang mendeskripsikan hubungan antara penyimpanan. digunakan untuk memodelkan struktur data dan hubungan antar data. ERD model dapat diuji dengan mengabaikan proses yang dilakukan [14]. Dapat dilihat pada Gambar 6.

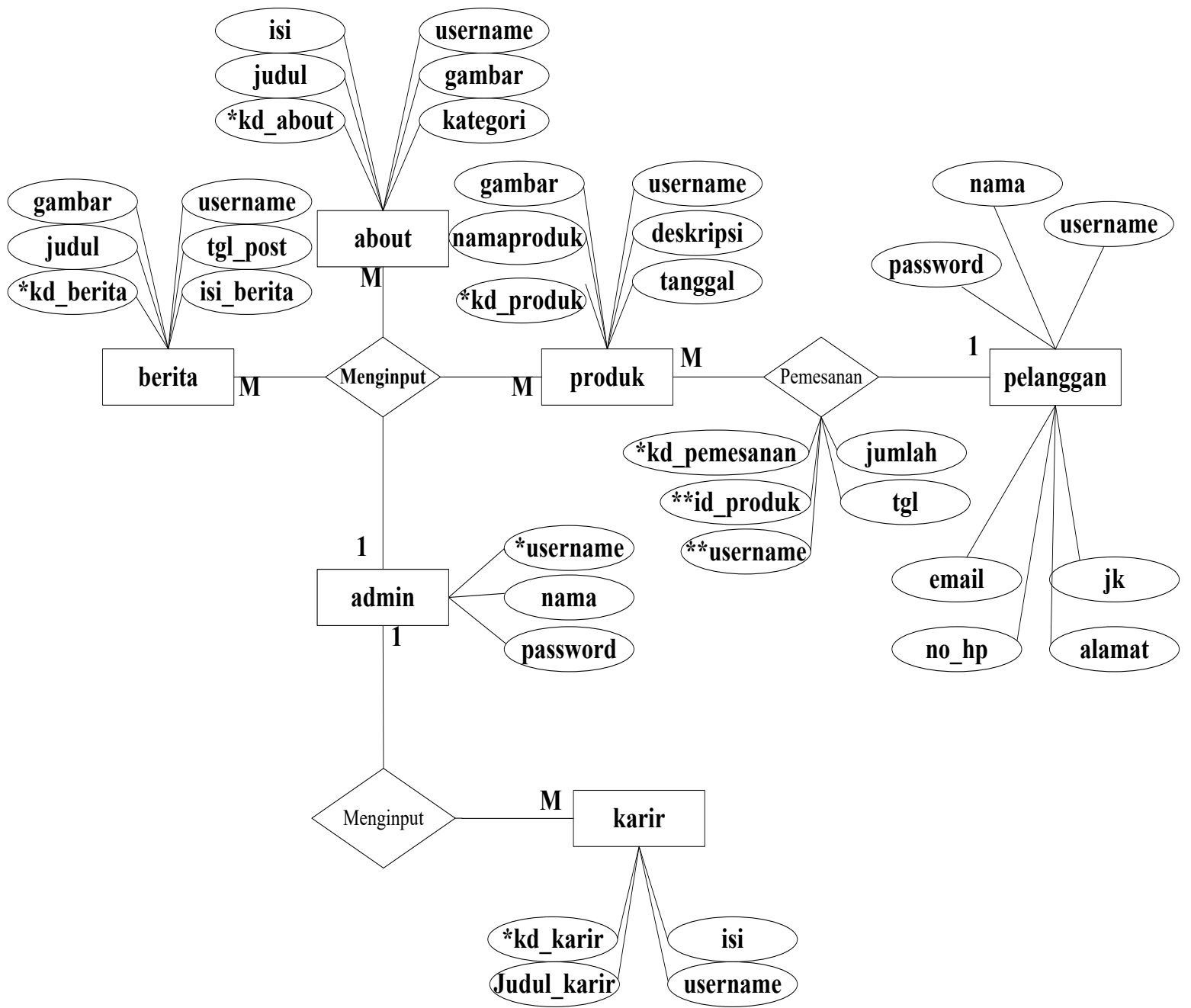

Gambar 6. Entity Relationship Diagram (ERD)

\subsubsection{Implementation (Implementasi)}

Untuk implementasi Perancangan tabel dalam database adalah hal yang pertama kali harus dilakukan sebelum membuat suatu aplikasi berbasis database [15]. Basis data bertujuan untuk menyimpan input data. Berikut ini adalah desain tampilan Website Media Informasi dan Pemesanan pada PT. Trita Musi Prasada:

\section{Tampilan Halaman Login}

Halaman login (Gambar 7) digunakan untuk akses masuk ke sistem dengan data yang yang sudah tersimpan di dalam database. 


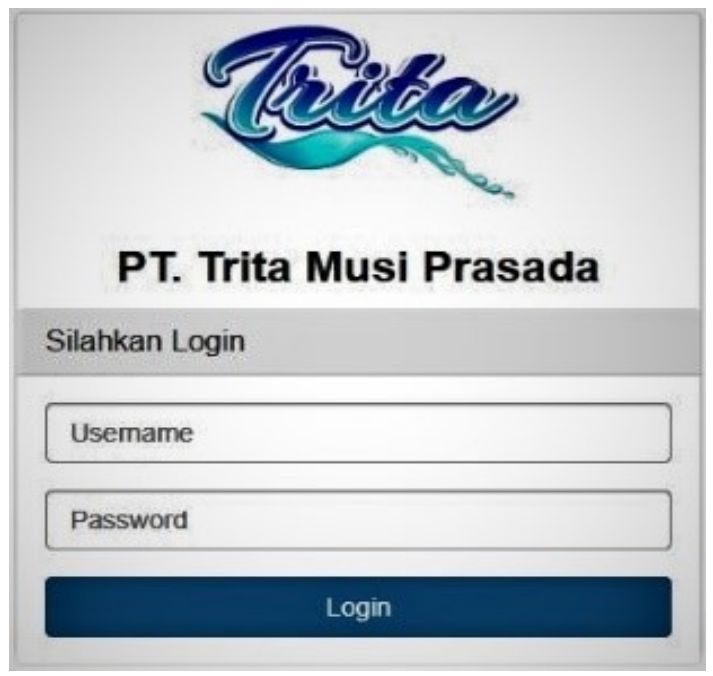

Gambar 7. Tampilan Halaman Login

\section{Tampilan Halaman Utama Admin}

Halaman utama berfungsi untuk menampilkan menu-menu produk yang akan ditawarkan PT. Tirta Musi kepada konsumen. Pada halaman ini berisi data profile, menu data barang, pemesanana, troly, dan fitur chat. Untuk halaman utama dapat dilihat pada Gambar 8.

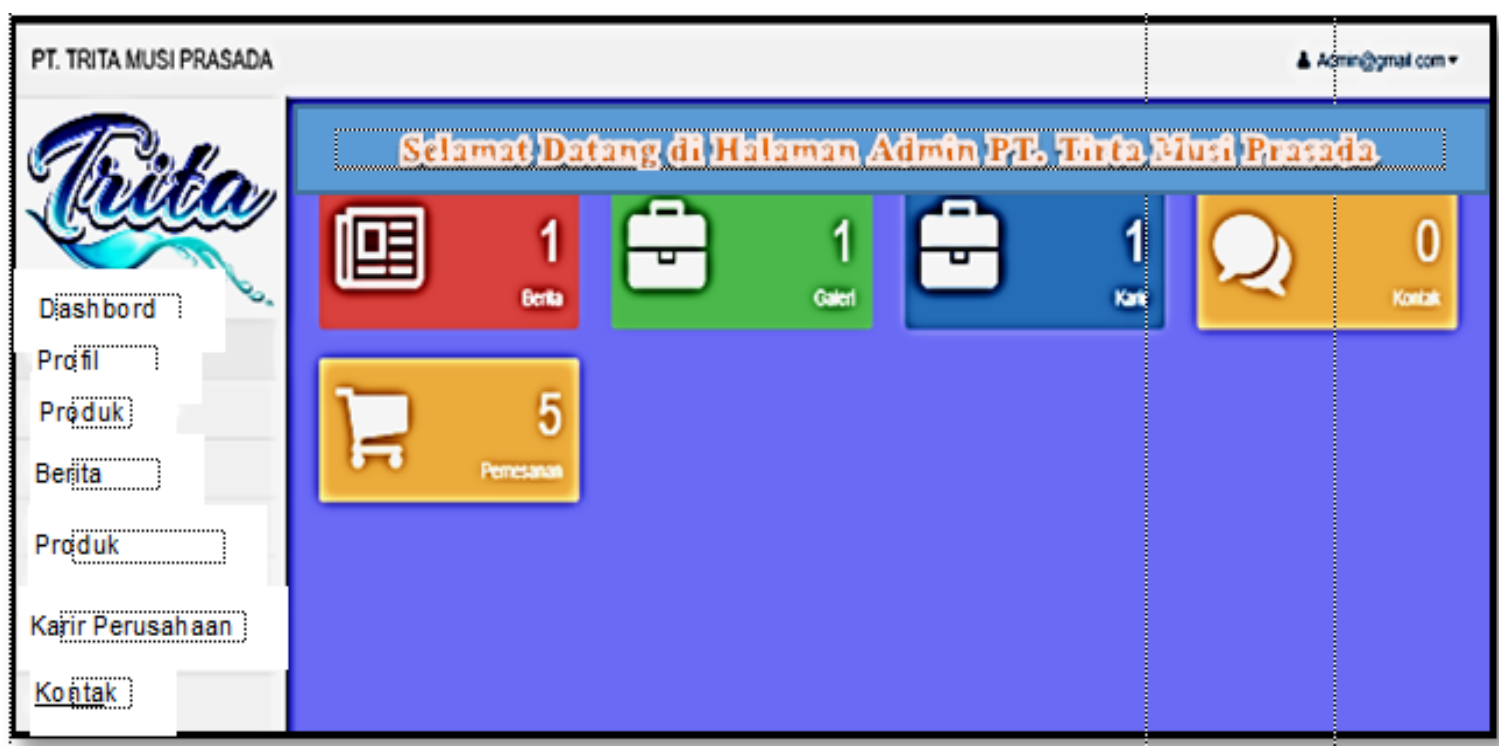

Gambar 8. Tampilan HalamanUtama Admin

\section{Tampilan Halaman Utama Pengunjung}

Halaman utama ini adalah halaman yang dapat diakses oleh pengunjung. Antarmuka halaman utama dapat dilihat pada Gambar 9. 


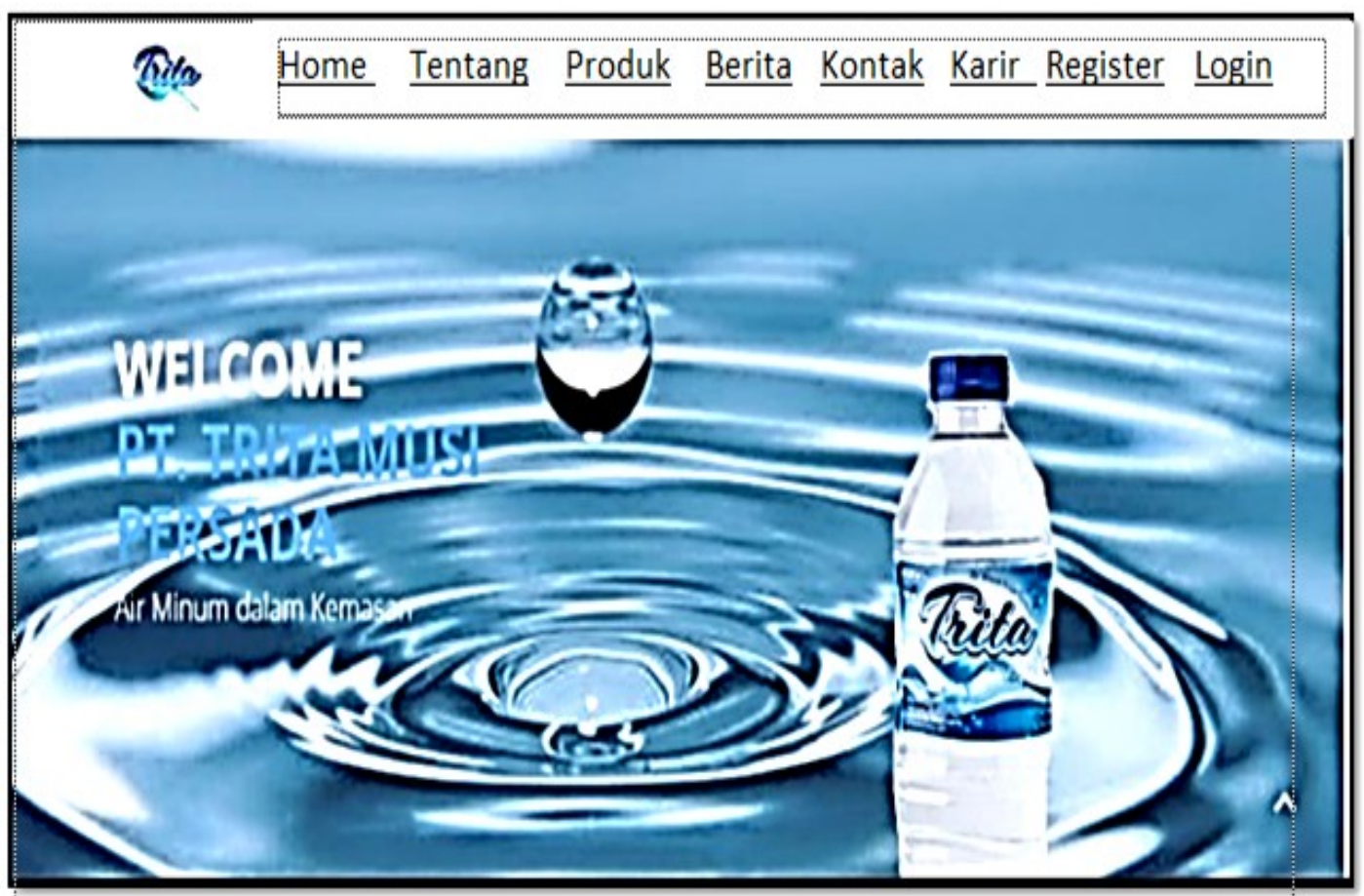

Gambar 9. Tampilan Halaman Utama Pengunjung

\section{Tampilan Halaman Produk}

Pada halaman ini menampilkan data produk yang tersedia pada PT. Trita Musi Prasada. Halaman ini dapat dilihat pada Gambar 10.

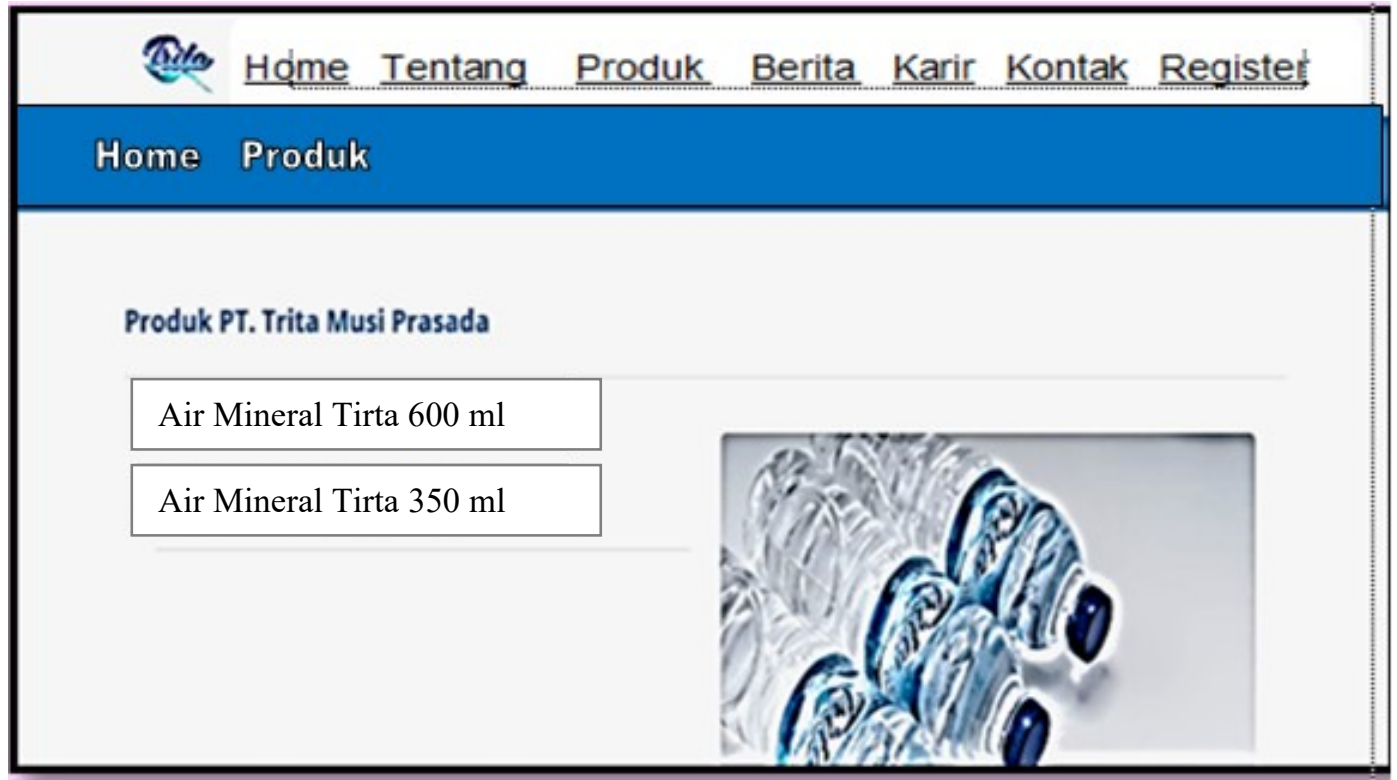

Gambar 10. Tampilan Halaman Produk

\section{Tampilan Halaman Pemesanan}

Halaman ini merupakan tampilan dari bagian pemesanan barang yang akan diorder oleh konsumen. Halaman pemesanan dapat dilihat pada Gambar 11. 


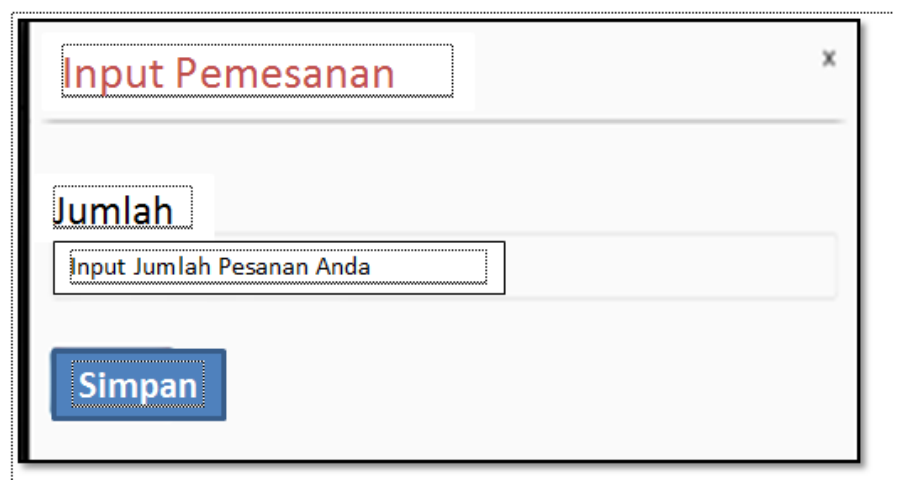

Gambar 11. Tampilan Halaman Pemesanan

\section{KESIMPULAN}

Dari pembahasan sebelumnya pada perancangan website media informasi dan pemesanan pada PT. Trita Musi Prasada dengan metode RAD ini dapat disimpulkan sebagai berikut:

1. Website Media Informasi dan Pemesanan pada PT. Trita Musi Prasada dapat memudahkan konsumen melakukan transaksi pemesanan produk secara online dan dapat diakes dari mana saja dan kapan saja.

2. Dengan adanya Website Media Informasi dan Pemesanan pada PT. Trita Musi Prasada ini dapat membantu bagian marketing untuk meningkatkan dan memperluas jangkauan pemasaran produk dan memperkenalkan perusahaan secara tidak langsung.

3. Website Media Informasi dan Pemesanan dapat membantu staf PT. Trita Musi Prasada dalam memanajemen penjualan produk.

\section{UCAPAN TERIMA KASIH}

Penulis mengucapkan terimakasih kepada Sekolah Tinggi Manajemen Iinformatiak dan Komputer Palcomtech, terkhusus untuk Lembaga Penelitian dan Pengabdian kepada Masyarakat (LPPM) dan PT. Trita Musi Prasada yang telah berkontribusi dalam memberikan support dan menjadi wadah tempat penulis melakukan penelitian.

\section{REFERENSI}

[1] R. A. Ristiyawati, "Perancangan Company Profile sebagai Media Promosi pada SP-Plast Sablon Ungaran Berbasis Multimedia Interaktif," Pixel : Jurnal Ilmiah Komputer Grafis, vol. 11, no. 1, pp. 1$11,2018$.

[2] J. R. Sagala, "Model Rapid Application Development (RAD) dalam Pengembangan Sistem Informasi Penjadwalan Belajar Mengajar," Jurnal Mantik Penusa, vol. 2, no. 1, pp. 87-90, 2018.

[3] M. P. Puteri and H. Effendi, "Implementasi Metode RAD Pada Website Service Guide 'Tour Waterfall South Sumatera,"” Jurnal Sisfokom (Sistem Informasi dan Komputer), vol. 7, no. 2, p. 130, Sep. 2018.

[4] B. D. Putranto, E. Utami, and A. Sunyoto, "Perancangan Sistem Penjadwalan Ujian Menggunakan Algoritma Genetika pada STMIK AMIKOM Purwokerto,” Jurnal Telematika, vol. 10, no. 2, pp. 106$120,2017$.

[5] M. A. Ramdhani and R. Rusmana, "Perancangan Sistem Proyek Pertunjukan Berbasis Web Menggunakan Metode RAD (Studi Kasus di Trans Studio Bandung)," Jurnal Informatika dan Sistem Informasi, vol. 11, no. 2, pp. 33-50, 2019.

[6] M. Rosaliza, "Wawancara, Sebuah Interaksi Komunikasi Dalam Penelitian Kualitatif," Jurnal Ilmu Budaya, vol. 11, no. 2, pp. 71-79, 2015.

[7] E. Agustina and T. Tobari, "Implementasi Pendidikan Karakter di SMP Negeri 1 Teluk Gelam dalam Mengatasi Sikap Primodialisme," Jurnal Manajemen, Kepemimpinan, dan Supervisi Pendidikan, vol. 2, no. 2, pp. 203-216, 2017.

[8] M. Destiningrum and Q. J. Adrian, "Sistem Informasi Penjadwalan Dokter Berbassis Web dengan Menggunakan Framework Codeigniter (Studi Kasus: Rumah Sakit Yukum Medical Centre)," Jurnal Teknoinfo, vol. 11, no. 2, p. 30, 2017.

[9] R. Abdulloh, Web Programming is Easy. Jakarta: PT Elex Media Komputindo, 2015.

[10] D. Susanti, E. Apriansya, and S. Suhelmi, "Sistem Informasi Karyawan pada Harian Umum Palembang 
Ekspres dengan Metode RAD,” Teknomatika, vol. 09, no. 02, pp. 197-208, 2019.

[11] I. Sari and E. Saputra, "Sistem Informasi Raport Berbasis Web Di Smp N 4 Temanggung," Data Manajemen dan Teknologi Informasi (DASI), vol. 15, no. 2, pp. 24-28, 2014.

[12] H. Herpendi, "Sistem Informasi Desa di Kecamatan Takisung," Jurnal Sains dan Informatika, vol. 3, no. 2, p. 76, 2017.

[13] D. Susanti, "Perancangan Sistem Informasi Penyaluran Bibit Unggul pada Dinas Pertanian Kabupten Pesisir Selatan," J-Click, vol. 7, no. 1, pp. 67-77, 2020.

[14] A. Adelia and J. Setiawan, "Implementasi Customer Relationship Management (CRM) pada Sistem Reservasi Hotel Berbasis Website dan Desktop," Jurnal Sistem Informasi, vol. 6, no. 2, pp. 113-126, 2011.

[15] T. Loveri, B. Harto, and D. Susanti, MySQL untuk Pemula. Padang: Pustaka Galeri Mandisi, 2019. 